\title{
Öğretmenlerin Öz Yeterlilik Kavramına İlişkin Algıları: Bir Olgubilim Araştırması
}

\author{
DOI: 10.26466/opus.603276
}

\author{
* \\ Sedat Alev* \\ * Dr, Milli Eğitim Bakanlığı / Gaziantep / Türkiye \\ E-Posta: sedat alv@hotmail.com \\ ORCID: $0000-0003-4506-4756$
}

\section{Öz}

Bu araştırmanın amacı, öğretmenlerin öz yeterlilik kavramına ilişkin algılarının belirlenmesidir. Araştırmada, olgubilim deseni kullanılmıştır. Çalışma grubu, 18 öğretmenden oluşmaktadır. Araştırmanın verileri yarı yapılandırılmış görüşme yöntemiyle toplanmıştır. Verilerin analizinde içerik analizi kullanılmış, her bir araştırmacı tarafından yapılan kodlamalarda, kodlayıcılar arası görüş birliği oranı 0.92 olarak hesaplanmıştır. Araştırma sonucunda, öğretmenlerin öz yeterlilik kavramına ilişkin görüşleri, "Planlama" alt teması altında; konu hakkında araştırma yapma, plan yapma, planları uygulayabilme yeterliliği, bir süre bekleme ve planlarda esnek davranma; "Başlama" alt teması altında; hedefe başlama yeterliliğ $i$, zor işleri deneme, hemen işe başlama, yeterliliklerini dikkate alma, konunun önem derecesi; "Sorun çözme" alt temasında; sorunların çözümünde yardım talep etme, anlaşmazlıkları çözmeye çalışma, beklenmedik sorunlarda olumsuz duygular hissetme, sorun çözmede zorluk yaşama, hedef belirlemede zorluk yaşama ve sorun çözmede yeterliliklerini göz önünde bulundurma; "Açıklama" alt temasinda; konuyu açıklama, ikna etmeye çalışma, doğru bilgiye ulaşmalar için destek olma şeklindedir. Öğretmenler "Yılmama" alt temasında ise; zorluklar karşısında pes etmeme, sorunlarla baş etme yeterliliği ve olumsuzluklardan ders çıkarma şeklinde görüş belirtmişlerdir. Öğretmenlerin öz yeterlilik algiların arttırmak amacıyla, bilgi ve becerilerini etkin bir şekilde kullanacakları ortamları oluşturulması ve bunu yaparken de başarısızlı̆̆a neden olabilecek engellerin ortadan kaldırılması önemlidir. Araştırma, ortaokullarda görev yapan öğretmenler üzerinde yapılmıştır. Bundan sonra yapılacak araştırmalar, farklı kademe ve örneklemlerde yapılabilir.

Anahtar Kelimeler: Öz yeterlilik, öğretmen, okul 


\title{
Teachers' Perceptions Regarding the Concept Self-Efficacy: A Phenomenological Study
}

\begin{abstract}
The aim of the research was to determine the teachers' perceptions regarding the concept self-efficacy. In this research, phenomenological design was used. Research group, consists of 18 teachers. The data of the research was carried out via semi-structured interviews. Content analysis were used in the analysis of the data and the interrater level of agreement based on the ratings of researchers was calculated as 0.92. As a result of this research, teachers' perceptions regarding the concept self-efficacy; under the sub-theme of "Planning" researching on the subject, planning, the ability to apply plans, waiting for a while and being flexible on the plans; under the sub-theme "Start"; ability to start the target, to try hard work, to start immediately, taking competence into account, importance of the subject; under the subtheme "Problem solving"; to seek help in resolving problems, to try to resolve disputes, to experience negative emotions in unexpected problems, to have difficulty in problem solving, to have difficulty in setting problems and to take their competence into account in problem solving; under the sub-theme "Description"; explaining the subject, trying to persuade, support to reach the right information. Teachers have expressed their opinions the theme of the sub-theme of "being undaunted" as; to stand firm under difficulties, to derive lessons from mistakes, ability to cope with problems. In order to increase teachers' self-efficacy perceptions, it is important to create environments where they can use their knowledge and skills effectively and to eliminate the obstacles that may cause failure. The research was conducted on teachers working in secondary schools. After that, researches can be done in different stages and samples.
\end{abstract}

Keywords: Self-efficacy, teacher, school 


\section{Giriş}

Öğretmenlik, öznesi insan olan bir meslektir ve bu meslekte alan bilgisinin yanı sıra olumlu insan ilişkileri ve sorun çözme becerileri ile ilgili yeterliklere sahip olmanın önemli olduğu bilinmektedir. Çünkü okullar bireyleri hayata hazırlayan, onların toplumla entegre olmalarını sağlayan, eğitim öğretim faaliyetleri sonucunda toplumun ihtiyaç duyduğu bilgi ve yeterliliklere sahip, donanımlı bireyler yetiştirmek gibi önemli bir misyona sahip kurumlardandır. Alev'e (2018) göre, toplumda eğitimli birey sayıs1nın giderek artmasıyla birlikte, çevrelerinde ve özellikle çalıştıkları kurumlarda gerek maddi olarak gerekse sosyal statülerini arttırmak, saygın biri haline gelmek için çeşitli şekillerde kendilerini ispatlamaya çalışan öğretmenler, performanslarını bu amaç doğrultusunda sergileme eğilimindedirler.

Albert Bandura'nın, 1986 yılında yazdığı 'Social Foundations of Thought and Action' adlı kitabında yer alan Sosyal Bilişsel Kuram'ın değişkenlerinden biri öz yeterliliktir. Kitapta, bireyin duygu, düşünce ve hareketlerini kontrol etmesine olanak sağlayan bir öz sisteme sahip olduğu belirtilmiştir (Pajares ve Schunk, 2002). İnsana bu gücü veren en önemli özellik ise, bireyin kendi yetkinlikleri hakkında sahip olduğu inançlardır ve bu inançlar, öz yeterlilik kavramı ile açıklanmaktadır (Işık, 2001). Öz yeterlilik, bireyin davranışları, çevre ve bireysel faktörler arasındaki ilişki olarak açıklanan sosyal bilişsel teoriden kaynaklanmaktadır (Bandura, 1997; McGee ve Wang, 2014; Prabhu, McGuire, Drost ve Kwong, 2012; Wood ve Bandura, 1989). Kuram, insan davranışının anlaşılması, tahmin edilmesi ve değiştirilmesi için önemli olmakla birlikte, birtakım davranışların nasıl kazanıldığı ve sürdürüldüğünü açıklamaktadır (Akar, 2011).

Literatürde yapılan çalışmalar incelendiğinde, öz yeterlilik ile ilgili farklı şekilde tanımlamalar yapıldığı görülmektedir. Bu tanımlara göre, öz yeterlilik; bireyin kendisinden beklenen durumları yönetmesini sağlayan, bir göreve ilişkin yapabileceklerine yönelik inancı (Bandura, 1995; Mitchell, Hopper, Daniels, George-Falvy ve James, 1994), bireyin bir işi yapabilmesi için gereken becerilere sahip olması (Temiz, 2009), bireyin kendi bilgi, beceri, yetenek ve kapasitesinin farkında olması (Bozbaş, 2015) ve bireyin gelecekte karşılaşabileceği güç durumların üstesinden gelmede ne kadar başarılı olabileceğine dair kendisi hakkındaki yargısı ve 
inancı (Yardımcı ve Başbakkal, 2010) gibi çeşitli şekillerde ifade edilmiştir. Tanımlardan anlaşılacağı üzere öz yeterlilik, bireyin herhangi bir konuda sahip olduğu bilgi ve becerinin, o konuda karşılaşabileceği sorunların üstesinden gelmede ne düzeyde etkili olabileceğine yönelik inancı şeklinde ifade edilebilir. Ancak bireyin, bir görevi başarıp başaramayacağı, yalnızca bilgiye, beceriye ya da önceki başarılara bakılarak tahmin edilememektedir. Çünkü bireylerin başarılı olacaklarına yönelik inançları ve daha önceki performans sonuçları, onların davranışlarını etkilemekte, çoğu zaman başarılı olacaklarına inandıkları görevleri yapmaya eğilimli iken, başarılı olacaklarına inanmadıkları görevleri yapmak istememektedirler (Krämer ve Winter, 2008; Tarkın ve Uzuntiryaki, 2012). Diğer bir ifadeyle, öz yeterlilik inancı, bireyin düşünce şeklini ve duygusal tepkilerini de etkilemektedir. Öz yeterlilik inancı yüksek olan birey başarısız olduğu zaman kararlı bir şekilde davranırken; öz yeterlilik inancı düşük olan birey kolaylıkla pes ederek devam etmekten vazgeçmektedir (Akbulut, 2006; Alev, 2018; Lombardo, 2006; Luszczynska, Scholz ve Schwarzer, 2005; Temiz, 2009). Kısaca ifade etmek gerekirse, öz yeterlilik algısı yüksek olan bireyler, bir işe başladıklarında süreç içerisinde karşılaşabilecekleri engellerle başa çıkmada daha başarılı olmakta, zorluklar karşısında pes etmeden hedefe ulaşmaya çalışmaktadırlar.

Öz yeterlilik inancının dört kaynağı bulunmaktadır. Bunlar; doğrudan deneyimler, dolaylı gözlem, sözel ikna ve psikolojik durumlar olarak sıralanmaktadır (Bandura, 1997; Scholz, Gutierrez- Dona, Sud ve Schwarzer, 2002; Wood ve Bandura, 1989). Doğrudan deneyimler, bireylerin kendisinin bizzat başardı ̆̆ 1 işlerden ya da yaptığı hatalardan meydana gelen deneyimler olup, güçlü bir yeterlilik inancının oluşmasını sağlamaktadır (Yurdakul ve Bostancı, 2016). Dolaylı gözlem, bireylerin, yalnızca kendi yaptıklarının sonuçlarını değerlendirmekle kalmayıp (Bandura, 1997); çevresindeki diğer kişileri gözlemleyerek ve onların deneyimlerinden faydalanarak öz yeterlilik inancını geliştirmesidir (Toy, 2015). Sözel ikna, öz yeterlilik inancının oluşmasında ya da artırılmasında önemlidir. İkna eden bireyin güvenilir ve konu hakkında yeterli bilgiye sahip olması ikna sürecini etkilemektedir. Psikolojik durumlarda, bireyin içinde bulunduğu ruhsal durum kişisel yeterlik inançlarını etkileyebilmekte; olumlu ruh hali kişisel yeterlik algısını güçlendirirken, olumsuz ruh hali ise zayıflatabilmektedir (Akbulut, 2015; Sakiz, 2007; Toy, 2015). 
Eğitim sistemlerinin başarısını belirleyen faktörler arasında kuşkusuz öğretmenlerin mesleki performansları da yer almaktadır. Öğretmenlerin mesleki performanslarının istenen düzeyde olabilmesi ise, sistem ya da okul düzeyindeki faktörlerin yanı sıra öğretmenlerin tutum, inanç ve davranışlarına yönelik bireysel faktörlere (kişilik algısı, geçmiş deneyimler, vb.) bağlıdır. Öğretmenlere ilişkin bu bireysel faktörler arasında, yeterlik algıları da yer almaktadır (Tschannen-Moran, Hoy ve Hoy, 1998). Bu kapsamda, öğretmenlerin öz yeterlilikleri ile ilgili çeşitli çalışmalar yapılmıştır (Atıc1, 2001; Goddard ve Goddard, 2001; Kiremit, 2006; Skaalvik ve Skaalvik, 2007). Yapılan bu çalışmalarda, öğretmenlerin öz yeterlik algılarının eğitim-öğretim faaliyetlerinin etkin bir şekilde yürütülmesinde, planlanmasında, karşılaşılan zorluklarla başa çıkmada ve öğrenci başarısı üzerinde önemli rolü olduğu belirlenmiştir.

Toplumdaki bireylerin eğitiminden ve geleceğe hazırlanmasından sorumlu olan öğretmenler, eğitim öğretim faaliyetleri esnasında çeşitli problemlerle karşılaşabilmekte ve bazı öğretmenler bu problemlerle daha kolay başa çıkabilmektedir (Alev ve Bozbayındır, 2018). Atıcı'ya (2001) göre öğretmenlerin sorunlarla başa çıkmasında sahip oldukları öz yeterlilik algıları önemli rol oynamaktadır. Ekici (2006) ve Karabacak (2014), öğretmen öz yeterliliğinin, özellikle öğretmen ve okul etkililiği için önemli olduğunu ifade etmişlerdir. Çünkü okullar bir ülkenin geleceğinin şekillendiği ve hammaddesi insan olan en önemli kurumlardan biridir. Bir ülkenin diğer kaynaklarının verimli biçimde kullanılması ve geliştirilmesi, insan kaynağının iyi yetiştirilmesi ve geliştirilmesine bağlı olduğundan, eğitim örgütlerinde çalışanların, özellikle öğretmenlerin mesleki açıdan yeterli olmalarını zorunlu kılmaktadır. Bu açıdan ele alındığında, toplumun insan kaynağını yetiştiren ve biçimlendiren öğretmenlerin öz yeterlilik algıları oldukça önem kazanmaktadır (Üstüner, Demirtaş, Cömert ve Özer, 2009). Kiremit (2006), öğretmenlerin, öğrencilerin öz yeterlilik algılarını etkileyeceğini ifade ederek, öğretmenlik mesleğinde, alan bilgisi yanında öz yeterlilik algısının yüksek düzeyde olması gerektiğini; Goddard, Hoy ve Hoy (2004), öğretmenlerin öz yeterlilik algılarının yüksek olmasının, karşılaştıkları sorunların ve engellerin üstesinden gelmelerinde ve başarısızlık karşısında pes etmemeleri üzerinde etkili olduğunu; Telef (2011) ise, güçlü öz yeterlilik algısına sahip öğretmenlerin güven, gayret, ısrar, çaba gibi spesifik ve gözlemlenebilir davranışlar sergilemeye istekli olduklarını 
vurgulamıştır. Bu bağlamda, öğretmen öz yeterliliğinin eğitim ortamında önemli rolü olduğunu söylemek mümkündür.

\section{Araştırmanın Önemi ve Amacı}

Öğretmen öz yeterliliğinin, öğretmenlerin sürekli çaba göstermeleri, istekli olmaları, bağlılık ve eğitimsel davranışları gibi olumlu çıtıların yanı sıra, başarı, motivasyon ve öz yeterlilik inancı gibi öğrenci çıktılarıyla da anlamlı ve güçlü bir ilişkisi olduğu bilinmektedir (Tschannen-Moran ve Hoy, 2001). Atıcı (2001), öz yeterlilik algısı düşük olan öğretmenlerin sınıf içerisinde öğrencileri daha fazla eleştirerek, öğrencilerin verdikleri yanlış cevapları düzeltip doğrusunu bulmalarında ısrar edeceklerini; öz yeterlilik algısı yüksek olan öğretmenlerin ise, öğrencilerin verdiği doğru cevaplardan sonra onları övme eğiliminde olduklarını belirtmektedir. Öğretmenlerin öğretme, sınıf yönetimi, araç gereç kullanımı, öğretim yöntem ve teknikleri, kişiler arası iletişim becerileri, kavramsal beceriler gibi çeşitli konularda yeterli düzeyde olmaları; verimli ve etkili bir eğitim-öğretim faaliyeti için önemlidir ve öğretmenlerin yüksek öz yeterlilik inancına sahip olmaları eğitim faaliyetlerini de olumlu yönde etkilemektedir (Bozbayındır ve Alev, 2018). Dolayısıyla, günümüzde en önemli kaynaklardan birisi olan insan kaynağının yetiştirilmesinde önemli rol oynayan okulların, çağın gereksinimlerine uyum sağlayabilmesi ve bilginin üretildiği, geliştirildiği, korunduğu, aktarıldığı kurumlar olarak bireylerin ve toplumun ihtiyaçlarına cevap verebilecek konumda olmaları gerekmektedir. Bunun için eğitim-öğretim faaliyetlerinden birinci derece sorumlu olan ögretmenlerin yeterli bilgi, beceri ve donanıma sahip olması, bu yeterliliklerini okulun ve öğrencilerin başarılı olması için kullanması önemli görülmektedir.

Çalışmada, öğretmenlerin öz yeterlilik kavramı hakkındaki algılarının ortaya çıkarılması amaçlanmıştır. Bu amaç doğrultusunda, öğretmenlerin öz yeterlilik ile ilgili kavramsal bilgileri, öz yeterlilik algıları, öz yeterliliğin eğitim-öğretim faaliyetlerindeki rolü ve işlevi hakkındaki görüşleri belirlenmiştir. 


\section{Yöntem}

\section{Araştırma Deseni}

Bu çalışmada, öz yeterlilik ile ilgili öğretmen görüşlerinin belirlenmesi amacıyla, nitel araştırma desenlerinden olgubilim (fenomenoloji) deseni kullanılmıştır. Olgubilim, bireylerin bir kavram veya bir olgu hakkında yaşadıkları deneyimleri tanımlamaya yöneliktir (Creswell, 2016). Olgubilim, günlük deneyimlerin anlamı veya doğası hakkında derinlemesine bir anlayışın kazanılmasını amaçlamaktadır (Patton, 2014; Yıldırım ve Şimşek, 2013). Çalışmada, eğitim ortamında önemli olduğu düşünülen (Goddard vd., 2004; Tschannen-Moran vd., 1998; Üstüner vd., 2009) öz yeterlilik kavramı, olgubilim deseniyle ele alınarak, öğretmenlerin öz yeterlilik kavramı ve öz yeterlilik algıları ile ilgili görüşlerinin, ilk elden ve öznel bir bakış açısıyla ayrıntılı bir şekilde incelemek için olgubilim deseni kullanılmıştır.

\section{Çalışma Grubu}

Olgubilim araştırmalarında veri kaynakları, araştırmanın odaklandığı olguyu yaşayan ve bu olguyu dişa vurabilecek bireyler veya gruplardır (Yıldırım ve Şimşek, 2013). Araştırmanın çalışma grubu Gaziantep ili Şahinbey ilçesindeki ortaokullarda görev yapan öğretmenlerden oluşmaktadır. Çünkü ortaokul öğrencilerinin dersin hedef davranışlarını yeterli düzeyde kazanmaları ve derse karşı olumlu tutum geliştirmeleri için öğretmenlerin yeterlilik düzeyinin önemli olduğu düşünülmektedir. Çalışma grubundaki öğretmenler, nitel araştırmalarda kullanılan başlıca örnekleme yöntemi olan; belli amaçlara dayalı olarak araştırma sorularının cevaplanmasıyla ilgili birimlerin (bireyler, gruplar, vb.) seçilmesi (Teddlie ve $Y u, 2007)$ şeklinde tanımlanan, amaçlı örneklem yöntemi ile seçilmiştir. Katılımcı sayısının belirlenmesinde, verilerin doygunluğa ulaştığı, diğer bir ifadeyle, yeni katılımcılardan toplanan verilerin eski verilerden elde edilen bulguların tekrarı olmaya başladığı, yeni kod ve temaların ortaya çıkmadığı durumlar göz önünde bulundurulmuştur (Corbin ve Strauss, 1990). Bu doğrultuda çalışma grubu, resmi ortaokullarda görev yapan 18 öğretmenden oluşmaktadır. Öğretmenlerin 7'si erkek, 11'i kadın; 10'u 
evli, 8'i bekârdır. Yaş değişkenine göre, 7'si 21-30 yaş arası, 9'u 31-40 yaş arası, 2'si 41 ve üzeri yaşta bulunmaktadır. Kıdem bakımından öğretmenlerin 9'u 1-9 yıl, 7'si 10-19 yıl, 2'si 20 yıl ve üzeri mesleki kıdeme sahiptir. Öğrenim durumuna göre öğretmenlerin 15'i lisans, 3'ü yüksek lisans derecesine sahiptir.

\section{Verilerin Toplanması}

Veri toplama aşamasına geçmeden önce çalışma grubundaki öğretmenlerin okullarının bağlı olduğu ilçe milli eğitim müdürlüğünden gerekli izin alınmıştır. Araştırmada veri toplamak amacıyla, yarı yapılandırılmış görüşme yöntemi kullanılmıştır. Görüşme, bilgi almak amacıyla görüşme yapan kişinin görüşülen kişiye birtakım sorular yönelttiği veri toplama yöntemidir (Christensen, Johnson ve Turner, 2015; Türnüklü, 2000). Teddlie ve Tashakkori (2015) görüşme yönteminin güçlü bir veri toplama yöntemi olduğu belirtmiştir. Çünkü araştırmacı ve görüşme yapılan kişi arasında birebir etkileşim bulunmaktadır ve görüşmeciye soruların cevaplarını açıklamak, sorunun anlaşılır olup olmadığını belirlemek için geniş bir zaman sunulmaktadır. Bu araştırmada yarı yapılandırılmış görüşme tekniği kullanılmıştır. Türnüklü (2000), yarı yapılandırılmış görüşme tekniğinde, araştırmacının önceden sormayı planladığı soruları içeren görüşme protokolünü hazırladığını; Yıldırım ve Şimşek (2013) ise görüşmecinin önceden hazırladığı konu veya alanlara sadık kalarak önceden hazırlanmış soruları sorma ve bu sorularla ilgili ayrıntılı bilgi almak için ek sorular sorma özgürlüğüne sahip olduğunu ifade etmiştir.

\section{Veri Toplama Araçlan}

Veri toplama aşamasında öğretmenlere öz yeterlilik ile ilgili yarı yapılandırılmış bir görüşme formu hazırlanmıştır. Soruların hazırlanması sürecinde, konuyla ilgili kapsamlı bilgilere ulaşmak amacıyla alan yazın taraması yapılarak öz yeterlilik ile ilgili ulusal ve uluslararası çalışmalar incelenmiştir. Yapılan incelemeler sonucunda görüşme formunda yer alması düşünülen maddeler belirlenmiştir. Maddelerin çalışmanın amacına ve kapsamına uygunluğunun değerlendirilmesi için Gaziantep Üniversitesi 
Eğitim Fakültesinde görev yapan üç öğretim üyesi, dil açısından incelemek üzere bir Türkçe öğretmeni ve eğitim yönetimi alanında yüksek lisans ve doktora yapan iki öğretmenin görüş ve önerileri dikkate alınmıştır. Üç öğretmen ile pilot uygulama yapılmıştır. Yapılan görüşmeler sonucunda bazı sorulardaki ifadeler anlaşılabilirlik açısından düzeltilmiş, daha açık bir şekilde ifade edilmiştir. Bu aşamalar sonucunda görüşme formuna son şekli verilmiştir.

Nitel bir araştırmada amaç, bilgilerin genellenmesinden ziyade özellikle spesifik açıklamaların yapılmasıdır (Creswell, 2016). Bu nedenle, görüşmeler gerekli izinler alındıktan sonra, okul müdürlerinin bilgisi dâhilinde 18 ortaokul öğretmeni ile görev yaptıkları okullarda gerçekleştirilmiştir. Görüşmelerde, görüşme kurallarına uygun olarak görüşme yap1lan yerin fiziki şartları kontrol edilmiş ve katılımcılarla rahat bir ortamda görüşme yapılmaya çalışılmıştır. Katılımcıların gönüllülüğü esas alınarak, yapılan görüşmeler ses kayıt cihazı ile kayıt altına alınmıştır. Görüşmeler araştırmacı tarafından randevular alınarak yaklaşık 30-45 dakika arasında değişen sürelerde yüz yüze gerçekleştirilmiştir. Öğretmenlere (K1: Kat1lımcı 1, K2: Katılımcı 2, K3: Katılımcı 3) şeklinde kodlar verilmiştir. Çalışma grubundaki öğretmenlere aşağıdaki sorular yöneltilmiştir.

1. Bir şey yapmaya karar verdiğinizde hemen işe girişir misiniz yoksa bir süre bekler misiniz? Nedenleriyle birlikte açıklar mısınız?

2. Zor ve karmaşık görünen bir konuyu öğrenmeniz gerektiği durumlarda nasıl davranışlar sergilediğinizden bahsedebilir misiniz?

3. Sorunlarla baş edebilme yeterliliklerinize güvenerek, yaptığınız işlerde ne düzeyde başarılı olacağınızı düşünüyorsunuz? Niçin?

4. Yeterli bilgi düzeyine sahip olduğunuzu düşündüğünüz bir konu hakkında sizinle aynı görüşte olmayan insanlara yaklaşımınız nasıl olur? Neden?

5. Yeni bir şey denerken, o işin zorluk düzeyi karşısında neler yaparsınız? Açıklar mısınız?

\section{Verilerin Analizi}

Verilerin analizinde, içerik analizi kullanılmıştır. İçerik analizi, nitel araştırmalarda yaygın kullanılan bir tekniktir (Stemler, 2001) ve analizi yapan araştırmacının, ne tür şeylerin bir örüntü oluşturacağına, neyin bir tema 
teşkil edeceğine, bu yapıya ne isim vereceğine karar vermesi gerekmektedir (Patton, 2014). İçerik analizi, araştırmacının elde ettiği bilgileri inceleyerek anlamlı bölümlere ayırmaya ve her bölümün kavramsal olarak ne ifade ettiği "verilerin kodlanması" aşaması, ortaya çıkan kodlardan yola çıkarak verileri, genel düzeyde açıklayabilen ve kodların belirli kategoriler altında toplandığ1 "temaların bulunması" aşaması, verilerin okuyucunun anlayacağ 1 şekilde kodlara ve temalara göre düzenlendiğ i "verilerin kodlara ve temalara göre düzenlenmesi ve tanımlanması" aşaması ve toplanan veriler arasındaki ilişkilerin açıklandığı "bulguların yorumlanması" aşaması olmak üzere dört aşamadan meydana gelmektedir (Yıldırım ve Şimşek, 2013).

İlk aşamada veriler bilgisayar ortamına aktarılarak her bir katılımcı için ham veri metinleri düzenlenmiştir. Verilerin analizi için kodlama anahtarı oluşturulmasında ve verilerin kodlanmasında MAXQDA 2018 nitel veri analizi programı kullanılmıştır. Kodların belirlenmesinde literatürde kullanılan kavramların yanı sıra görüşme sonucunda ortaya çıkan verilerden yararlanılmıştır. Daha sonra ortaya çıkan kavramlar arasındaki ortak noktalar göz önünde bulundurularak tematik kodlama yapılmış ve temalar oluşturulmuştur. Tematik kodlama yapılırken, temaların altında bulunan kavramların anlamlı bir bütün oluşturmasına, temaların ve alt temaların birbirleriyle anlamlı bir bütün oluşturmasına dikkat edilmiştir. Temalar ve kodlar birbirleri ile ilişkili bir şekilde düzenlenerek, araştırmanın amacına yönelik olarak yorumlara ve düşüncelere yer verilmiştir. Katılımcıların görüşleri verilirken, belirli görüşleri örnekleyen ifadelere yer verilmesine özen gösterilmiştir. Verilen ifadenin öncesinde veya sonrasında görüşün devam ettiğini belirtmek için, [...] işareti kullanılmıştır.

\section{Geçerlik ve Güvenirlik Çalışmaları}

Araştırmada, geçerlik ve güvenirlik çalışmaları kapsamında, inandırıcılık (iç geçerlilik), aktarılabilirlik (dış geçerlilik), tutarlılık (iç güvenirlik) ve tekrar edilebilirlik (dış güvenirlik) (Erlandson vd., 1993, akt. Yıldırım ve Şimşek, 2013) çalışmaları yapılmıştır. İnandırıcılık, gözlenen ilişkinin nedensel olduğuna yönelik araştırmacının çıkarımının ne derece doğru olup olmadığıdır (Christensen vd., 2015). İnandırıcılığın sağlanması için, katı- 
lımcılarla yapılan görüşmelerin süresi mümkün olduğu kadar uzun tutulmaya çalışılmıştır. Bunun yanı sıra, araştırma konusu ve nitel araştırma yöntemleri hakkında uzman kişilerle birlikte, veri toplama süreci, veri analizi ve sonuçları ile ilgili incelemeler yapılmıştır. Uzman görüşlerinden yararlanarak araştırmacılar tarafından hazırlanan görüşme soruları üç öğretmene okutularak soruların doğru şekilde ifade edilip edilmediği ve anlaşılabilirliği ile ilgili kontroller yaptırılmıştır. Görüşmeler bilgisayar ortamında yazıya aktarılmış, katılımcılara okutularak kendi görüşlerini yansitıp yansıtmadığı kontrol ettirilmiştir. Araştırma sonuçlarının farklı ortamlara ne derece taşınabildiği, uygunluğu ve genellenebilirliği aktarılabilirlik olarak ifade edilmektedir (Miles ve Huberman, 2015). Bu amaçla, ayrıntılı betimleme yapılmış ve katılımcıların görüşlerinden doğrudan alıntılara yer verilmiştir (Yıldırım ve Şimşek, 2013). Tutarlılık, çalışma sürecinin zaman, araştırmacı ve mekân karşısında görece sabit olmasıdır (Miles ve Huberman, 2015). Tutarlığın sağlanması amaciyla, verilerin kodlanma sürecinde yapılan kontrollerin yeterliliği ve veri analizi esnasında bu kodların uygun temalarda bir araya getirilmesine özen gösterilmiştir. Buna ek olarak, eğitim yönetimi alanında dört uzmanın görüşüne başvurularak, verilerin çözümlenmesinde bağımsız kodlayıcılar arasındaki tutarlılık sağlanmaya çalışılmıştır. Miles ve Huberman'ın (1994) formülü (Güvenirlik= görüş birliği/görüş birliği+görüş ayrılığ1 X 100) kullanılarak yapılan hesaplamalarda kodlayıcılar arasındaki görüş birliği oranı 0.92 olarak belirlenmiştir. Araştırmacının araştırmanın temel aşamaları ve araştırma sürecindeki kendi konumu ve yaklaşımı konusunda ayrıntılı ve açık bilgi vermesi (Yıldırım ve Şimşek, 2013) olarak ifade edilen tekrar edilebilirlik çalışmaları kapsamında, görüşme süreci, analiz süreci ve elde edilen sonuçların sunumu ile ilgili mümkün olduğunca ayrıntılı açılamalara yer verilmiştir.

\section{Bulgular}

Öğretmenlerin öz yeterlilik ile ilgili kavramsal bilgileri, öz yeterlilik alg1ları, öz yeterliliğin eğitim-öğretim faaliyetlerindeki rolü ve işlevini belirlemeye yönelik olarak yapılan içerik analizi sonucunda öz yeterlilik; "Planlama", "Başlama”, "Sorun Çözme”, “Açılama/İkna" ve "Yılmama” 
alt temalarında kodlanmıştır. Tematik ve kavramsal kodlamalar Tablo 1 'de sunulmuştur.

Tablo 1. Öz Yeterlilik Kavramına Dair Yapılan Tematik ve Kavramsal Kodlamalar

\begin{tabular}{|c|c|c|c|}
\hline Tema & Alt Tema & Kavramsal Kodlamalar/Kavramlar ve Alt Kavramlar & $f$ \\
\hline \multirow{22}{*}{ 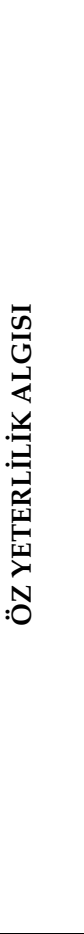 } & \multirow{5}{*}{ Planlama } & Konu hakkında araştırma yapma & 13 \\
\hline & & Plan yapma & 12 \\
\hline & & Planları uygulayabilme yeterliliği & 10 \\
\hline & & Bir süre bekleme & 9 \\
\hline & & Planlarda esnek davranma & 7 \\
\hline & \multirow{5}{*}{ Başlama } & Hedefe başlama yeterliliği & 15 \\
\hline & & Zor işleri deneme & 12 \\
\hline & & Hemen işe başlama & 8 \\
\hline & & Yeterlilikleri dikkate alma & 5 \\
\hline & & Konunun önem derecesi/katkısı & 3 \\
\hline & \multirow{6}{*}{ Sorun Çözme } & Sorunların çözümünde yardım talep etme & 14 \\
\hline & & Anlaşmazlıkları çözmeye çalışma & 12 \\
\hline & & $\begin{array}{l}\text { Beklenmedik sorunlarda olumsuz duygular (panik, } \\
\text { kayg1) hissetme }\end{array}$ & 8 \\
\hline & & Sorun çözmede zorluk yaşama & 5 \\
\hline & & Hedef belirlemede zorluk yaşama & 5 \\
\hline & & $\begin{array}{l}\text { Sorun çözmede yeterliliklerini göz önünde bulun- } \\
\text { durma }\end{array}$ & 4 \\
\hline & \multirow{3}{*}{ Açılama/İkna } & Konuyu açıklama (farklı kaynaklar vb.) & 16 \\
\hline & & İkna etmeye çalışma & 11 \\
\hline & & Doğru bilgiye ulaşmaları için destek olma & 4 \\
\hline & \multirow{3}{*}{ Y1lmama } & Zorluklar karşısında pes etmeme & 17 \\
\hline & & Sorunlarla baş etme yeterliliği & 13 \\
\hline & & Olumsuzluklardan ders çıkarma & 5 \\
\hline
\end{tabular}

Tablo 1'de görüldüğü üzere, öğretmenlerin öz yeterlilik kavramı ile ilgili görüşleri, "planlama, başlama, sorun çz̈zme, açıklama/ikna ve yılmama" olmak üzere beş alt tema altında ortaya çıkmıştır. "Planlama" alt teması altında ortaya çıkan alt kavramlar sırasıyla; konu hakkında araştırma yapma ( $\mathrm{f}=13)$, plan yapma ( $\mathrm{f}=12)$, planları uygulayabilme yeterliliğ $\mathrm{i}(\mathrm{f}=10)$, bir süre bekleme $(\mathrm{f}=9)$ ve planlarda esnek davranma $(\mathrm{f}=7)$ şeklindedir.

Öğretmenler, "Planlama" alt teması altında en fazla konu hakkında araştırma yapma ile ilgili görüş belirtmişlerdir. Bir konuyu öğrenme sırasında ya da bir işe başlarken öncelikle çeşitli kaynaklardan araştırma yaparak yeterli bilgiye sahip olduktan sonra işe başlayacağını belirten öğret- 
menlerden biri konu ile ilgili olarak düşüncelerini, "[...] eğger konuyu bilmiyorsam araştırırım. Kütüphaneye giderim, elektronik ortamda ve internette araştırma yaparım. O konuda neler yapılması gerekiyorsa onu yaparım, asla pes etmem. Bunun yanı sıra uğraşırım, o konu hakkında bilgi sahibi olan kişilere veya idari bir konuysa idarecime sorarım. Bir şekilde pes etmem yani, öğrenmeye çalışırım (K1)." şeklinde ifade etmiştir. Konu hakkında araştırma yapmak ile ilgili görüş belirten öğretmenlerden biri ise düşüncelerini şu şekilde ifade etmiştir: "Ĕğer bir şeyi hobi amaçl ya da kendi kişisel gelişimim için öğrenmek istiyorsam daha bireysel öğrenme metotların deniyorum. İnternetten, bilişim ă̆larından yararlanıyorum, araştırma yapıyorum veya çeşitli kurslara giderek konu hakkında bilgi sahibi olmaya çalışıyorum (K16)." Görüldüğü üzere, bir konuyu öğrenmeye başlamadan önce konu ile ilgili çeşitli kaynaklardan araştırma yapma, yeterli olduğu düşünülen kişilerden bilgi alma ve konuyu öğrenmek için pes etmeden yapılması gerekenleri yapma gibi davranışların sergilendiği görülmektedir. Konu hakkında araştırma yapmanın yanı sıra, bir işe başlamadan önce plan yapmanın önemi ve gerekliliği hakkında öğretmenlerden biri ise görüşlerini şu şekilde ifade etmiştir: "Bir işe karar verdiğgimde hemen uygulamaya koymayı düşünmem. Önce basamak basamak ilerlemeyi tercih ederim. Çünkü aniden alınmış bir karar belki beni olumsuz bir sonuca da götürebilir. Önce düşünür, planımı kafamda bir tasarlarım, daha sonra uygulamaya geçerim (K11)." Burada ifade edilen görüşe göre de, bir işe başlamadan önce yapılacak işin artılarını ve eksilerini göz önünde bulundurarak yaşanabilecek olumsuzlukları en aza indirgemek için planlamanın önemine atıfta bulunulmuştur.

Öğretmenler "Başlama" alt teması altında görüşlerini sırasıyla; hedefe başlama yeterliliği ( $\mathrm{f}=15)$, zor işleri deneme $(\mathrm{f}=12)$, hemen işe başlama $(\mathrm{f}=8)$, yeterliliklerini dikkate alma $(\mathrm{f}=5)$ ve konunun önem derecesi/katkısı $(\mathrm{f}=3)$ şeklinde ifade etmişlerdir. Bir işe başlarken nasıl bir yol izledikleri, neler yaptıkları ile ilgili olarak en çok belirledikleri hedefe başlama konusunda yeterli oldukları yönünde görüş belirtmişlerdir. Hedef belirleme ve belirlenen hedefleri gerçekleştirme konusunda yeterli olduğunu düşünen öğretmenlerden biri düşüncelerini, "Hedef belirleme, bu hedeflere zamanında başlama ve hedefe ulaşma konusunda kendimi yeterli görüyorum. Bir hedef koyuyorum, o hedef doğrultusunda yapılması gereken neyse onları yapmaya çalışıyorum ve onu özellikle sonlandırmaya çalışıyorum. Yani yarım bırakılan işlerden 
hiç hoşlanmam genelde. Ya hiç başlamam ya da başladıysam bitiririm (K2)." şeklinde ifade etmiştir. Bu görüşten anlaşılacağı üzere, konu hakkındaki düşüncelerini ifade eden öğretmenlerden bazıları hedef belirleme, belirlenen hedefe ulaşma konusunda yeterli olduklarını ve hedefi gerçekleştirmeye yönelik davranışlarda bulunacaklarını belirtmektedirler. Bunun yanı sıra, başlanan bir hedefi sürdürme ve istenilen sonuca ulaşma konusunda öğretmenlerden biri şu şekilde görüş belirtmiştir: "Bir hedefim varsa azimliyimdir, mücadele ederim, kararl olurum, pes etmem yani elimden gelen her şeyi yaparım. Çünkü sonuçta hedefe ulaşma amacı vardır. Öğrencilere yararlı bir çalışma varsa o hedefe ulaşmak ve sonucu elde etmek için mücadele ederim (K7)." $\mathrm{Bu}$ ifadede, başlanan hedefleri azimli bir şekilde devam ettirme, hedefe ulaşmak için çaba harcama ve özellikle öğrencilere faydalı olma konularına dikkat edildiği görülmektedir.

Öğretmenler, öz yeterlilik ile ilgili olarak "Sorun çözme" alt teması altında sırasıyla; sorunların çözümünde yardım talep etme $(\mathrm{f}=14)$, anlaşmazlıkları çözmeye çalışma ( $\mathrm{f}=12)$, beklenmedik sorunlarda olumsuz duygular (panik, kaygı) hissetme $(\mathrm{f}=8)$, sorun çözmede zorluk yaşama $(\mathrm{f}=5)$, hedef belirleme/sürdürmede zorluk yaşama $(f=5)$ ve sorun çözmede yeterliliklerini göz önünde bulundurma $(\mathrm{f}=4)$ şeklinde görüş belirtmişlerdir. Sorunlar karşısındaki davranışları ve sorun çözme konusundaki yaklaşımları ile ilgili olarak öğretmenlerden biri görüşlerini şu şekilde ifade etmiştir: "İhtiyacım olduğu zaman çevremden aldığım yardımların sorunlarımı çözmemde yardımcı olduğunu düşünüyorum. Çünkü sizin düşünemediğiniz bir şeyi başka kişiler düşünebilir, çözemediğiniz bir sorunu başkaları kolay bir şekilde çözebilir. Akıl akıldan üstündür sonuçta (K13)." Bu ifadeden, öğretmenlerin bazılarının ihtiyaç duyulduğu takdirde diğer insanlardan yardım talebinde bulunarak sorunları çözmeye çalışacakları, farklı görüş ve düşüncelere önem verdikleri anlaşılmaktadır. Buna ek olarak, anlaşmazlıklardan kaynaklanan sorunlar olduğu zaman sorunlara neden olan anlaşmazlıkların çözümü için çaba gösterme ve anlaşmazlıkları ortadan kaldırarak sorunları çözmeye çalışma konusunda görüş belirten öğretmenlerden biri düşüncelerini şu şekilde ifade etmiştir: "[...] eğger bir meslektaşımla anlaşmazlık olmuşsa ve bana karşı hatalı veya yanlış bir davranışta bulunulmuşsa bu durumda öncelikle bunun sebebini öğrenmeye ve onlarm anlayabileceği bir seviyede, konuşarak iletişim kurup problemi çözmeye çalışırım (K4)." Burada ifade edildiği üzere, meslektaşlarla yaşanabilecek anlaşmazlıklar olduğunda, 
kendisine karşı yanlış davranışlar sergilendiğini düşünen öğretmenler iletişimin önemini vurgulamış ve problemi çözmeye yönelik çalışmalar yapacaklarını belirtmişlerdir.

"Açılama" alt temasında ise sırasıyla; konuyu açıklama ( $\mathrm{f}=16)$, ikna etmeye çalışma ( $\mathrm{f}=11)$, doğru bilgiye ulaşmaları için destek olma ( $\mathrm{f}=4)$ şeklinde görüş belirtilmiştir. Öğretmenler yeterli oldukları bir konuda o konu hakkında yeterli bilgiye sahip olmayan insanlara çeşitli açıklamalar yaparak doğru bilgiye ulaşmaları için onlara destek olduklarını ve ikna etmeye çalıştıklarını ifade etmişlerdir. Bu konuda görüş belirten öğretmenlerden biri düşüncelerini şu şekilde ifade etmiştir: "[...] eğer dedikleri gerçekten yanlışsa ve yanlışı savunmaya devam ediyorlarsa bu durumda onları yanlışların bulmaya yönlendiririm. Tabi doğrudan sizin düşünceniz yanlış, sakın bu şekilde yapmayın, yerinize oturun vb. ifadeler kullanmam ama onlara düşüncelerinin yanlı̧̧ olduğunu bulduracak sorular sorarak ikna etmeye çalışırım, eğer bilgimin yeterli ve doğru olduğuna inanıyorsam (K3)." Başka bir öğretmen ise, "Konu hakkında yeterli bilgim olduğunu düşünüyorsam karşı tarafı ikna etmeye çalışırım. Çünkü konuya hakimsem zaten o konuyu biliyorumdur. Herkes tarafindan da doğru olarak kabul ediliyorsa, göreceli değilse, günlük hayattan çeşitli örnekler vererek, ilginç olaylar anlatarak, karşı tarafı ikna etmeye çalışırım (K6)." şeklinde görüş belirtmiştir. Bu ifadelerden, öğretmenlerin yeterli olduklarını düşündükleri bir konuda karşı taraf üzerinde olumsuz bir izlenim oluşturmaktan kaçınarak konu ile ilgili açılama yapma ve onları ikna etme davranışı sergileyecekleri anlaşılmaktadır.

Öğretmenler, "Yılmama" alt teması altında sırasıyla; zorluklar karşısinda pes etmeme $(\mathrm{f}=17)$, sorunlarla baş etme yeterliliğ $\mathrm{i}(\mathrm{f}=13)$ ve olumsuzluklardan ders çıkarma $(\mathrm{f}=5)$ şeklinde görüş belirtmişlerdir. Yeterli olduğunu düşünen öğretmenlerin büyük bir kısmı karşılaştıkları zorluklar karşısında pes etmeme davranışı göstereceklerini belirtmişlerdir. Zorluklar karşısında pes etmeden başladığı işe devam etme ve sonuca ulaşma odaklı olduğunu ifade eden öğretmenlerden birinin görüşü şu şekildedir: "Ben biraz tuttuğunu koparan bir insanım. Öyle hemen kolay vazgeçen bir insan değilim. Karakter meselesi bence. Bir eksiklik varsa bunu tamamlamak benim görevimdir. İşi layıkıyla yapabilmek de önemli benim için. Hayata bakış açım da böyle, sadece ders açısından değil [...] (K9)." Görüldüğü üzere, bazı öğretmenler zorluklar karşısında pes etmeyerek, mesleki anlamda eksiklikle- 
rini tamamlayarak, görevin gereklerini hakkıyla yerine getirmeye çalışacaklarını belirtmişlerdir. Zor işlere başlarken veya bu işleri devam ettirirken karşılaşılan beklenmedik sorunlar/aksaklıklar karşısında ne tür davranışların sergilendiği konusunda öğretmenlerden biri ise düşüncelerini şu şekilde ifade etmiştir: "Beklenmedik sorunlar, aksaklıklar olması durumunda o işi başarana kadar uğraşırım. Çünkü onun benim bir görevim ve sorumluluğum olduğunu düşünürüm. Öğrenciyken genelde pes edebiliyordum. Ama artık mesleğe başladı̆̆ımdan itibaren zorlandığım durumlarda, başarana kadar uğraşıyorum (K15)." Bu ifadeden, öğretmenlerden bazılarının yaşanabilecek beklenmedik sorunlar veya aksaklıklar karşısında görev bilinci içerisinde, toplum içindeki konumlarını da göz önünde bulundurarak buna göre davranışlar sergileyecekleri anlaşılmaktadır.

\section{Tartışma, Sonuç ve Öneriler}

Bu bölümde araştırma sonucu ortaya çıkan bulguların ilgili alan yazınla ilişkilendirilmesine dayalı olarak çıkarımlara yer verilmiştir. Öz yeterlilik kavramı ile ilgili öğretmen görüşleri incelendiğinde, öğretmenlerin genel anlamda kendilerini yeterli gördükleri ve görüşlerini bu doğrultuda ifade ettikleri belirlenmiştir. Yapılan bazı araştırmalarda (Çimen, 2007; Özkurt, 2017; Toy, 2015; Tschannen-Moran ve Hoy, 2001; Turcan, 2011) da araştırma bulgularını destekler nitelikte öğretmenlerin öz yeterlilik algılarının yeterli düzeyde olduğu sonucu elde edilmiştir. Ancak araştırma sonucunda öğretmenler yeterlilikleri hakkında çoğunlukla olumlu görüş belirtmelerine rağmen; Üstüner vd. (2009) tarafından ortaöğretim öğretmenlerinin öz yeterlilik algıları ile ilgili yapılan bir araştırma sonucunda ise öğretmenlerin öz yeterlilik algılarının orta düzeyde olduğu belirlenmiştir.

Öğretmenler öz yeterlikleri ile ilgili olarak bir işe başlarken planlama yaptıklarını, o işe başlamadan önce konu ile ilgili çeşitli kaynaklardan (internet, kitap vb.) yararlandıklarını, konunun önem derecesine ve yeterliliklerine göre bazen bir süre bekleyip eksiklerini tamamladıktan sonra işe başlayacaklarını belirtmişlerdir. Bu bulguları destekler nitelikte Tschannen-Moran vd. (1998) öz yeterlilik algısı yüksek olan öğretmenlerin yeni fikirlere açık ve öğrencilerinin ihtiyaçlarına yönelik yeni metotları denemeye daha istekli olduklarını, planlama ve organize etme konusunda da diğer öğretmenlere göre daha iyi olduklarını ifade etmiştir. Görüşme 
yapılan öğretmenlerin büyük bir kısmı, hedefe başlama ve hedeflerini gerçekleştirme konusunda yeterli olduklarından, karşılaşacakları sorunlar karşısında pes etme davranışı göstermeyeceklerinden bahsetmişlerdir. Bu konuda, Goddard vd. (2004), öğretmenlerin öz yeterlilik algılarının yüksek olmasının, israrcı bir şekilde engellerin üstesinden gelmelerinde ve başarısızlık karşısında pes etmemeleri üzerinde etkili olduğunu; Telef (2011), güçlü öz yeterlilik algısına sahip öğretmenlerin güven, gayret, ssrar, çaba gibi spesifik ve gözlemlenebilir davranışlar sergilemeye istekli olduklarını; Akbulut (2006) ise, öz yeterlilik inancı yüksek olan öğretmenlerin yaptıkları işlerde daha kararlı davranışlar sergileyeceklerini ifade ederek öz yeterliliğin önemini vurgulamıştır.

Öz yeterlilik, hedef belirleme ve belirlenen hedeflere bağlllık göstererek bu yönde performans sergilenmesini olumlu yönde etkilemektedir (Lombardo, 2006; Luszczynska vd., 2005). Temiz (2009) tarafından yapilan bir araştırmada, öğretmenlerin öz yeterlilik inancının yüksek olmasının daha yüksek performans göstermelerini sağlayacağı belirtilmiştir. Benzer şekilde, öz yeterlilik ile ilgili olarak öğretmen örnekleminde yapılan çeşitli araştırmalarda da (Alev ve Bozbayındır, 2018; Alev, 2018), öz yeterlilik inancı yüksek olan öğretmenlerin eğitim öğretim faaliyetleri esnasında gerek sınıf içerisinde gerekse okul ortamında yapılan faaliyetlerde etkin rol alacakları, kararlı davranışlar sergileyecekleri ve zorluklarla mücadele ederek, kolay kolay pes etmeyecekleri ifade edilmiştir. Bu ifadelerden anlaşılacağı üzere, öz yeterlilik inancı yüksek olan öğretmenler, yaptıkları işte olumsuz sonuç almaları ve başarısız olmaları durumunda dahi, pes etmemekte, o işi tamamlamak ve işin üstesinden gelmek için çaba göstermeye çalışmaktadırlar.

Elde edilen bir diğer bulguya göre, öğretmenler bir işe başlarken işin zorluğunu ve öz yeterliliklerini göz önünde bulundurmaktadırlar. Bu sonucu destekler şekilde, Kotaman (2008) öz yeterliliği, bireyin belli bir görevi başarabileceği konusundaki inancı olarak tanımlamış ve bu inancın bireyin bir işe başlayıp başlamamasını, başladığı işi devam ettirmesini ve sonuç olarak performansını olumlu yönde etkilediğini ifade etmiştir. Pajares ve Schunk (2002), öz yeterlilik algısı yüksek olan bireylerde zorlukları başaracağına inanma, kaygının azalması, öz saygı ve direncin artması gibi durumlar gözlemlendiğini belirtirken; Yenilmez ve Kakmacı (2008), öz yeterlilik algısı yüksek olan bireylerin, zorlu görevler karşısında 
daha rahat davrandığını; Ayık, Savaş ve Yücel (2015) ise yüksek öz yeterliliğe sahip olan bireylerin, zor hedefler seçerek bu hedefleri sürdürmede daha ısrarcı olduklarını belirtmiştir. Buna göre, öz yeterliliğin öğretmenlerin zorluklarla mücadele etmesinde, eğitim-öğretimin hedeflerini gerçekleştirmesinde önemli bir rolü olduğunu söylemek mümkündür.

Öz yeterlilik düzeyi yüksek olan öğretmenler eğitimle ilgili işlere daha fazla zaman ayırarak, zorluklar karşısında öğrencilere yol göstererek, akademik başarılarını artırmak için çalışırken; öz yeterlilik düzeyi düşük olan öğretmenler ise, akademik olmayan aktivitelere daha fazla zaman ayırmaktadırlar (Dolgun, 2016). Araştırma sonucunda da öğretmenler, "açılama" alt teması altında, öğrencilere yeterli oldukları bir konuyla ile ilgili bilgi verirken, farklı kaynaklardan açıklama yaptıklarını, farklı yöntem ve teknikleri kullandıklarını ve doğru bilgiye ulaşmaları için çaba gösterecekleri ve öğrencilere destek olacakları yönünde görüş belirtmişlerdir. Diğer bir ifadeyle öğretmenler bir konuda yeterli olduklarını düşündükleri zaman, öğrencileri ikna etmek için daha çok çaba göstermektedirler.

Araştırma sonuçlarına yönelik olarak hem uygulayıcılar hem de araştırmacılar için çeşitli önerilerde bulunmak mümkündür. Öğretmenlerin öz yeterlilik algılarını arttırmak amacıyla, bilgi ve becerilerini etkin bir şekilde kullanacakları ortamların oluşturulması ve bunu yaparken de başarısızlığa neden olabilecek engellerin ortadan kaldırılması önemlidir. Buna ek olarak, öğretmenlerin yeterliliklerini arttırmak, kendilerini geliştirmelerini sağlamak ve mesleki anlamda gelişimlerini teşvik etmek için maddi (maaş karşılığı ödüllendirme vb.) veya simgesel ödüller (başarı belgesi, teşekkür belgesi, plaket vb.) çeşitli ödüller verilerek motive edilmelerinin önemli olduğu düşünülmektedir. Bu çalışmadan elde edilen sonuçlar, Gaziantep il merkezinde görev yapan öğretmenlerden elde edilen verilere dayanmaktadır. Araştırma nitel yöntemle yürütülmüş olup, sonuçların genellenebilmesi için nicel yöntemle araştırmaların yapılması ve sonuçların karşılaştırılması yararlı olacaktır. Araştırma resmi ortaokullarda görev yapan öğretmenler üzerinde yapılmıştır. Bundan sonra yapılacak araştırmalar, özel okullar örnekleminde ve farklı kademelerde yapılarak elde edilecek sonuçlar karşılaştırılabilir. Öğretmenlerin yanı sıra yöneticilerin öz yeterlilik ile ilgili görüşlerini belirlemeye yönelik araştırmalar yapılabilir. 


\title{
EXTENDED ABSTRACT
}

\section{Teachers' Perceptions Regarding the Concept Self-Efficacy: A Phenomenological Study}

\author{
Sedat Alev \\ Ministry of National Education
}

Teaching is an occupation whose subject is human and it is known that it is important to have competencies related to positive human relations and problem solving skills in addition to their field knowledge and expertise competencies. Because schools are institutions that prepare individuals for life, enable them to integrate with the society, have an important mission such as educating well-equipped individuals who have the knowledge and competences required by the society as a result of education and training activities. With the increasing number of educated individuals in the society, teachers who try to prove themselves in various ways to increase their financial and social status, to become a respectable person in their environment and especially in the institutions they work at, they are performing towards achieving this purpose. In the meantime, they know their own self-efficacy by knowing what they can and cannot do for starters, so that they make impressions about themselves.

Various researches have been conducted on self-efficacy in educational organizations (Atıc1, 2001; Cheng, 2015; Goddard and Goddard, 2001; Kiremit, 2006; Kleinsasser, 2014; Skaalvik and Skaalvik, 2007; TschannenMoran at., 1998). Teachers, who are responsible for educating individuals in the society and preparing them for the future, may encounter various problems during activities of education and some teachers can deal with these problems more easily (Alev and Bozbayındır, 2018). According to Atici (2001), self-efficacy perceptions play an important role in teachers' coping with problems. Ekici (2006) and Karabacak (2014) stated that teacher self-efficacy is particularly important for teacher and school effectiveness. Because schools are one of the most important institutions in which the future of a country is shaped and the raw material is human. Since the efficient use and development of other resources of a country depends on 
the good education and development of human resources, it is compulsory that the employees in the education organizations, especially the teachers, should be professionally competent. From this point of view, self-efficacy perceptions of teachers shaping the human resources of society are gaining importance (Üstüner at., 2009).

It is important for teachers to have adequate level of teaching, classroom management, use of tools, teaching methods and techniques, interpersonal communication skills, conceptual skills for efficient and effective educational activity, and teachers' high self-efficacy beliefs also positively affect their educational activities (Bozbayındır and Alev, 2018). Therefore, schools that play an important role in the training of human resources, which is one of the most important sources of our day, should be able to adapt to the needs of the age and to be able to respond to the needs of individuals and society as the institutions in which information is produced, developed, protected and transferred. For this purpose, it is considered important for teachers who are first degree liable for education activities to be efficacious. The aim of the research was to determine the teachers' perceptions regarding the concept self-efficacy.

In this research, phenomenological design of qualitative research designs was used to determine the opinions of teachers about self-efficacy. Phenomenology is intended to describe individuals' experiences about a concept or a case (Creswell, 2016). Phenomenology aims to gain an indepth understanding of the meaning or nature of everyday experiences (Patton, 2014; Yıldırım and Şimşek, 2013). In this research, the concept of self-efficacy, which is thought to be important in the educational environment, is examined with phenomenology pattern and the opinions of teachers about self-efficacy are examined in depth and in detail. Research group, consists of 18 teachers working at secondary schools.

In order to collect data, semi-structured interview method was used. During the preparation of the questions, a literature review was conducted in order to obtain comprehensive information about the subject and national and international researches on self-efficacy were examined. As a result of the investigations, the items to be included in the interview form were determined. Pilot scheme is conducted with three teachers after the expert opinion was obtained in order to evaluate the suitability of the 
items for the purpose and scope of the research. As a result of the interviews, the statements in some of the questions were corrected in terms of intelligibility and expressed more clearly. As a result of these stages, the interview form was put into its final form and directed to the teachers in the research group. In the analysis of the data, content analysis were used. In the first stage, the data was transferred to the computer and raw data texts were arranged for each participant. MAXQDA 2018 qualitative data analysis program was used to generate coding key for data analysis and to encode data. In addition to the concepts used in the literature, the data obtained from the interview were used to determine the codes. Thematic coding was made and themes were formed considering the common points between the concepts that emerged later.

Teachers' opinions on self-efficacy are as; under the sub-theme of "Planning" researching on the subject, planning, the ability to apply plans, waiting for a while and being flexible on the plans; under the sub-theme "Start"; ability to start the target, to try hard work, to start immediately, taking competence into account and importance of the subject / contribution; in the "Description" sub-theme; explaining the subject, trying to persuade, support to reach the right information. Teachers have expressed their opinions under the theme of "Problem solving" as; to seek help in resolving problems, to try to resolve disputes, to experience negative emotions in unexpected problems, to have difficulty in problem solving, to have difficulty in setting/maintaining problems and to take their competence into account in problem solving; under the sub-theme of "being undaunted" as; to stand firm under difficulties, to derive lessons from mistakes, ability to cope with problems. In order to increase teachers' selfefficacy perceptions, it is important to create environments where they can use their knowledge and skills effectively and to eliminate the obstacles that may cause failure. The research was conducted on teachers working in secondary schools. After that, researches can be done in different stages and samples. 


\section{Kaynakça / References}

Akar, Ö. (2011). İlköğretim okullarının başarı durumlarına göre yöneticilerin duygusal zekâlar ile öğretmenlerin özyeterlilikleri arasındaki ilişkinin belirlenmesi:Ankara ili örneği. Yayımlanmamış doktora tezi. Gazi Üniversitesi, Ankara.

Akbulut, E. (2006). Müzik öğretmeni adaylarının mesleklerine ilişkin özyeterlik inançları. Yüzüncü Yıl Üniversitesi Eğitim Fakültesi Dergisi, 3(2), 2433.

Akbulut, H. S. (2015). The relationship between writing self-efficacy and writing performance in a university english preparatory course. Unpublished master of arts. Çukurova Üniversitesi, Adana.

Alev, S. (2018). Öğretmenlerin genel öz yeterlilik algılarn ile duygusal emek davranışları arasındaki ilişkinin incelenmesi: İzlenim yönetimi taktiklerinin aracllk rolü. Yayımlanmamış doktora tezi, Gaziantep Üniversitesi, Gaziantep.

Alev, S. ve Bozbayındır, F. (2018). Öğretmenlerin genel öz yeterlilik algıları, izlenim yönetimi taktikleri kullanımları ve duygusal emek davranışları arasındaki ilişki. Kırşehir Ĕ̆itim Fakültesi Dergisi, 19(3), 1788-1807.

Atıc1, M. (2001). Yüksek ve düşük yetkinlik düzeyine sahip öğretmenlerin s1nıf yönetimi stratejileri. Kuram ve Uygulamada Ĕ̆itim Yönetimi Dergisi, 7(4), 483-499.

Ayık, A., Savaş, M. ve Yücel, E. (2015). İlkokullarda görev yapan okul müdürlerinin genel öz yeterlik ile örgütsel bağlılık algıları arasındaki ilişkinin incelenmesi. Uşak Üniversitesi Sosyal Bilimler Dergisi, 8(2), 193-218.

Bandura, A. (1995). Exercise of personal and collective efficacy in changing societies. In (A. Bandura Ed). Self-efficacy in changing societies, Cambridge: Cambridge University Press.

Bandura, A. (1997). Self-efficacy: The exercise of control. New York, NY: Freeman. Bozbaş, Y. (2015). Sınıf öğretmenlerinin öz yeterlilik inançları ve sinıf yönetimi beceri algıları arasındaki ilişki. Yayımlanmamış yüksek lisans tezi. İstanbul Aydın Üniversitesi, İstanbul.

Bozbayındır, F. ve Alev, S. (2018). Öğretmenlerin öz yeterlilik, proaktif kişilik ve değişime açıklık algıları arasındaki ilişkinin incelenmesi. İnönü Üniversitesi Ĕ̆itim Fakültesi Dergisi, 19(2), 293-311.

Christensen, L. B., Johnson, R. B. ve Turner, L. A. (2015). Araştırma yöntemleri: Desen ve analiz. (Çev. Ed. A. Aypay). Ankara: Anı Yayıncllık. 
Corbin, J. M. ve Strauss, A. (1990). Grounded theory research: Procedures, canons, and evaluative criteria. Qualitative Sociology, 13(1), 3-21.

Creswell, J. V. (2016). Nitel araştırma yöntemleri: Beş yaklaşıma göre nitel araştırma ve araştırma deseni. (Çev. Ed. M. Bütün ve S. B. Demir). Ankara: Siyasal Kitabevi.

Çimen, S. (2007). Illköğretim öğretmenlerinin tükenmişlik yaşantıları ve yeterlik algıları. Yayımlanmamış yüksek lisans tezi. Kocaeli Üniversitesi, Kocaeli.

Dolgun, H. (2016). İngilizce öğretmenleri ve öğretmen adaylarmın özyeterlilik algı profili. Yayınlanmamış yüksek lisans tezi. Akdeniz Üniversitesi, Antalya.

Ekici, G. (2006). Meslek lisesi öğretmenlerinin öğretmen öz-yeterlik inançlari üzerine bir araştırma. Eurasian Journal of Educational Research (EJER), 24, 87-96.

Goddard, R. D. ve Goddard, Y. L. (2001). A multilevel analysis of the relationship between teacher and collective efficacy in urban schools. Teaching and Teacher Education, 17, 807-818.

Goddard, R. D., Hoy, W. K. ve Hoy, A. W. (2004). Collective efficacy beliefs: theoretical developments, empirical evidence, and future directions. Educational Researcher, 33(3), 3-13.

Işık, İ. (2001). Öz-yeterlilik inancı: Yönetici rolleri açısından bir inceleme. Yayımlanmamış doktora tezi. Marmara Üniversitesi, İstanbul.

Karabacak, M. (2014). Ankara ili genel liselerinde görev yapan öğretmenlerin özerklik algıları ile özyeterlik algıları arasındaki ilişki. Yayımlanmamış yüksek lisans tezi. Ankara Üniversitesi, Ankara.

Kiremit, H. Ö. (2006). Fen bilgisi öğretmenliği öğrencilerinin biyoloji ile ilgili özyeterlik inançlarının karşılaştırılması. Yayımlanmamış doktora tezi. Dokuz Eylül Üniversitesi, İzmir.

Kotaman, H. (2008). Özyeterlilik inancı ve öğrenme performansının geliştirilmesine ilişkin yazın taraması. Uludă̆ Üniversitesi Eğitim Fakültesi Dergisi, 21(1), 111-133.

Krämer, N. C. ve Winter, S. (2008). Impression management 2.0: The relationship of self-esteem, extraversion, self-efficacy, and self-presentation within social networking sites. Journal of Media Psychology, 20(3), 106-116.

Lombardo, T. (2006). Thinking ahead: The value of future consciousness. The Futurist, 40(1), 45-50. 
Luszczynska, A., Scholz, U. ve Schwarzer, R. (2005). The general self-efficacy scale: Multicultural validation studies. The Journal of Psychology, 139(5), 439- 457.

McGee, J. R. ve Wang, C. (2014). Validity-supporting evidence of the self-efficacy for teaching mathematics instrument. Journal of Psychoeducational Assessment, 32(5), 390-403.

Miles, M. B. ve Huberman, A. M. (1994). Qualitative data analysis: A sourcebook of new methods. Thousand Oaks, CA: Sage.

Miles, M. B. ve Huberman, A. M. (2015). Nitel veri analizi. (Çev. Ed. S.A. Altun ve A. Ersoy). Ankara: Pegem Akademi.

Mitchell, T. R., Hopper, H., Daniels, D., George-Falvy, J. ve James, L. R. (1994). Predicting self-efficacy and performance during skill acquisition. Journal of Applied Psychology, 79, 506-517.

Özkurt, M.F. (2017). Sınıföğretmenlerinin öz yeterlilik algılar ile öğretim teknolojileri ve materyal tasarım becerileri arasındaki ilişki. Yayımlanmamış yüksek lisans tezi. Necmettin Erbakan Üniversitesi, Konya.

Pajares, F. ve Schunk, D. H. (2002). Self and self-belief in psychology, education: A historical perspective. In J. Aronson (Ed.). Improving academic achievement: Impact of psychological factors on education (pp. 3-21). San Diego, CA: Academic Press.

Patton, M. Q. (2014). Nitel araştırma ve değerlendirme yöntemleri. (Çev. Ed. M. Bütün ve S.B. Demir). Ankara: Pegem Akademi.

Prabhu, V. P., McGuire, S. J., Drost, E. A. ve Kwong, K. K. (2012). Proactive personality and entrepreneurial intent: Is entrepreneurial self-efficacy a mediator or moderator? International Journal of Entrepreneurial Behavior $\mathcal{E}$ Research, 18(5), 559-586.

Sakiz G. (2007). Does teacher affective support matter? An investigation of the relationship among perceived teacher affective support, sense of belonging, academic emotions, academic self-efficacy beliefs and academic effort in middle school mathematic classrooms. Unpublished doctoral dissertation. The Ohio State University, USA.

Scholz, U., Gutierrez- Dona, B., Sud, S. ve Schwarzer, R. (2002). Is general selfefficacy a universal construct? European Journal of Psychological Assessment, 18(3), 242-251.

Skaalvik, E.M. ve Skaalvik, S. (2007). Dimensions of teacher self-efficacy and relations with strain factors, perceived collective teacher efficacy, and teacher burnout. Journal of Educational Psychology, 99(3), 611-625. 
Stemler, S. (2001). An overview of content analysis. Practical Assessment, Research E Evaluation, 7(17), 137-146.

Tarkın, A. ve Uzuntiryaki, E. (2012). Öğretmen adaylarının özyeterlik inançları ve mesleğe yönelik tutumlarının kanonik korelasyon analizi ile incelenmesi. İlköğretim Online, 11(2), 332-341.

Teddlie, C. ve Tashakkiro, A. (2015). Karma yöntem araştırmalarının temelleri. (Çev. Ed. S. B. Demir ve Y. Dede). Ankara: Anı Yayıncılık.

Teddlie, C. ve Yu, F. (2007). Mixed methods sampling: A typology with examples. Journal of Mixed Methods Research, 1(1), 77-100.

Telef, B. B. (2011). Öğretmenlerin öz-yeterlikleri, iş doyumları, yaşam doyumları ve tükenmişliklerinin incelenmesi. İlköğretim Online, 10(1), 91-108.

Temiz, M. (2009). Halk eğitimi merkezlerinde görevli mesleki teknik ve sosyal- kültürel kursları öğretmenlerinin öz yeterlilik düzeylerinin incelenmesi. Yayımlanmamış yüksek lisans tezi. Marmara Üniversitesi, İstanbul.

Toy, S. N. (2015). Sınıföğretmenlerinin öğretmen öz yeterlikleri ile kaynaştırma eğitimine ilişkin yeterlik inançlarının karşılaştırılması. Yayımlanmamış yüksek lisans tezi. Pamukkale Üniversitesi, Denizli.

Tschannen-Moran, M., Hoy, A. W. ve Hoy, W. K. (1998). Teacher efficacy: Its meaning and measure. Review of Educational Research, 68(2), 202-248.

Tschannen-Moran, M. ve Hoy, A. W. (2001). Teacher efficacy: Capturing an elusive construct. Teaching and Teacher Education, 17(7), 783-805.

Turcan, H.G. (2011). İlköğretim okulu öğretmenlerinin öz yeterlilik algıları ile iş doyumları arasındaki ilişkinin incelenmesi. Yayımlanmamış yüksek lisans tezi. Selçuk Üniversitesi, Konya.

Türnüklü, A. (2000). Eğitimbilim araştırmalarında etkin olarak kullanılabilecek nitel bir araştırma tekniği: Görüşme. Kuram ve Uygulamada Ĕ̆gitim Yönetimi Dergisi, 6(4), 543-559.

Üstüner, M., Demirtaş, H., Cömert, M. ve Özer, N. (2009). Ortaöğretim öğretmenlerinin öz-yeterlik algıları. Mehmet Akif Ersoy Üniversitesi Ĕ̆itim Fakültesi Dergisi, 9(17), 1-16.

Wood, R. ve Bandura, A. (1989). Social cognitive theory of organizational management. Academy of Management Review, 14(3), 361-384.

Yardımcı, F. ve Başbakkal, Z. (2010). Ortaokul öz-yeterlilik ölçeğinin geçerlilik ve güvenilirlik çalışması. Anadolu Psikiyatri Dergisi, 11(4), 321-326.

Yenilmez, K. ve Kakmacı, Ö. (2008). İlköğretim matematik öğretmenliği bölümü öğrencilerinin öz yeterlilik inanç düzeyleri. Eskişehir Osmangazi Üniversitesi Sosyal Bilimler Dergisi, 9(2), 1-21. 
Yıldırım, A. ve Şimşek, H. (2013). Sosyal bilimlerde nitel araştırma yöntemleri (9. baskı). Ankara: Seçkin Yayıncılık.

Yurdakul, A. ve Bostancı, A. B. (2016). Öğretmenlerin okulların örgütsel narsizm düzeylerine yönelik görüşleri ile öz yeterlilik algıları arasındaki ilişki. Kırıkkale Üniversitesi Sosyal Bilimler Dergisi, 6(1), 109-125.

\section{Kaynakça Bilgisi / Citation Information}

Alev, S. (2019). Öğretmenlerin öz yeterlilik kavramına ilişkin algıları: Bir olgubilim araştırması. OPUS-Uluslararası Toplum Araştırmaları Dergisi, 14(20), 956-981. DOI: 10.26466/opus.603276 